\title{
Effect of thawing methods on frozen semen quality of yak (Poephagus grunniens L.) bulls
}

Binod Kumar Dutta Borah ${ }^{1}$, Bharat Chandra Deka², Ranjan Kumar Biswas ${ }^{2}$, Prithiviraj Chakravarty ${ }^{1}$, Sourabh Deori ${ }^{1}$, Sudip Sinha ${ }^{2}$ and Kutubuddin Ahmed ${ }^{2}$

1. ICAR-National Research Centre on Yak, Dirang-790101, Arunachal Pradesh, India;

2. Department of Animal Reproduction, Gynaecology and Obstetrics, College of Veterinary Science, Assam Agricultural University, Khanapara, Guwahati -781022, Assam, India.

Corresponding author: Sourabh Deori, e-mail: sourabhd1@rediffmail.com, BKDB: beekeyvet@gmail.com, BCD: bcdeka@gmail.com, RKB: rkbiswascvsc@rediffmail.com, PC: drpcicar@gmail.com, SS: sinhasudip58@gmail.com, KA: kahmedj@gmail.com

Received: 28-02-2015, Revised: 01-06-2015, Accepted: 11-06-2015, Published online: 07-07-2015

doi: 10.14202/vetworld.2015.831-834 How to cite this article: Borah BKD, Deka BC, Biswas RK, Chakravarty P, Deori S, Sinha S, Ahmed K (2015) Effect of thawing methods on frozen semen quality of yak (Poephagus grunniens L.) bulls, Veterinary World 8(7): 831-834.

\begin{abstract}
Aim: To evaluate different thawing temperatures and duration on the post-thaw semen quality of Indian yaks bulls.

Materials and Methods: Semen ejaculates from four different yak bulls were collected using artificial vagina method and extended with tris extender containing $6.4 \%$ glycerol at $35^{\circ} \mathrm{C}$, cooled gradually from $35^{\circ} \mathrm{C}$ to $5^{\circ} \mathrm{C}$ at $1{ }^{\circ} \mathrm{C} / 3$ min and equilibrated at $4-5^{\circ} \mathrm{C}$ for $4 \mathrm{~h}$ and frozen in French mini straws using a programmable bio-freezer and finally stored in liquid nitrogen. Thawing of frozen semen straws was carried out using three methods i.e., $35^{\circ} \mathrm{C}$ for $60 \mathrm{~s}$ (thawing method I), $37^{\circ} \mathrm{C}$ for $30 \mathrm{~s}$ (thawing method II) and $75^{\circ} \mathrm{C}$ for $9 \mathrm{~s}$ (thawing method III). The post-thaw semen quality parameters assessed were sperm motility, percent live sperm, hypo-osmotic swelling test (HOST)-reacted sperm, acrosomal changes, and alanine aminotransferase (ALT) and aspartate aminotransferase (AST) activities in the extracellular media.
\end{abstract}

Results: The percent sperm motility, total incidence of acrosomal changes, and extracellular release of AST varied significantly $(\mathrm{p}<0.01)$ between thawing methods but live sperm and HOST-reacted sperm did not vary significantly between thawing methods. The percent sperm motility of frozen yak semen for thawing method III was significantly $(p<0.05)$ higher than that for thawing methods I and II, the difference between thawing methods I and II being non-significant. The critical difference test revealed that the total incidence of acrosomal changes and extracellular release of AST were significantly $(\mathrm{p}<0.05)$ lower when thawing was done using methods I and II than in method III.

Conclusion: On the basis of the present experiment, we can conclude that barring the post-thaw sperm motility, thawing of frozen yak semen in water either at $35^{\circ} \mathrm{C}$ for $60 \mathrm{~s}$ or $37^{\circ} \mathrm{C}$ for $30 \mathrm{~s}$ gives better post-thaw semen quality than at $75^{\circ} \mathrm{C}$ for $09 \mathrm{~s}$.

Keywords: acrosomal changes, post-thaw, thawing methods, semen quality, yak.

\section{Introduction}

Thawing of frozen semen brings back the frozen spermatozoa to life and to the physiologically active state. Therefore, it is essential to carry out thawing carefully at an optimal temperature for sufficient time to minimize the loss of semen quality during thawing procedure.

Worldwide, different workers conducted trials to determine the optimal thawing temperature and duration, and to know the adequate thawing rate that may result in the highest percentage of viable spermatozoa in different species after thawing process $[1,2]$. However, such study was not reported for Indian yak bull's semen.

In India, yak is distributed throughout the $3000 \mathrm{~km}$ of snow-bound Himalayan range starting from the Kashmir Valley of Northwest India to Arunachal Pradesh in the east. Standardization of

Copyright: The authors. This article is an open access article licensed under the terms of the Creative Commons Attributin License (http:// creative commons.org/licenses/by/2.0) which permits unrestricted use, distribution and reproduction in any medium, provided the work is properly cited. artificial insemination technique in this species can go a long way for genetic dissemination of superior germplasm under field conditions and ex situ conservation of this valuable highland species.

Therefore, the present study was undertaken with an objective to evolve a suitable thawing protocol for yak bull semen and its effect on post-thaw semen quality.

\section{Materials and Methods}

\section{Ethical approval}

This study was conducted after approval by the Research Committee and Institutional Animal Ethics Committee.

\section{Semen collection and processing}

Semen ejaculates were collected by artificial vagina from apparently healthy yak bulls aged 3-4.5 years, maintained at the yak farm of the ICAR National Research Centre on Yak, Dirang, Arunachal Pradesh, India. The bulls were maintained under similar managerial conditions and fed with concentrate mixture comprising maize grain, wheat bran, mustard cake, groundnut cake, soyabean meal, mineral 
mixture, and salt at $2-2.5 \mathrm{~kg} / \mathrm{bull} / \mathrm{day}$ along with seasonal green grasses and tree leaves ad libitum.

Immediately after collection, the semen was evaluated for color, volume, mass activity, and initial sperm motility using standard methods. A total of 15 ejaculates having a minimum volume of $1.00 \mathrm{ml}$, mass activity $3+$ and initial sperm motility $70 \%$ were used for processing and freezing. The semen samples were extended (1:10) with tris extender containing $6.4 \%$ glycerol at $35^{\circ} \mathrm{C}$, cooled gradually from $35^{\circ} \mathrm{C}$ to $5^{\circ} \mathrm{C}$ at $1^{\circ} \mathrm{C} / 3 \mathrm{~min}$ and equilibrated at $4-5^{\circ} \mathrm{C}$ for $4 \mathrm{~h}$. Following equilibration, freezing of semen in French mini straw was done using a programmable bio freezer (Mini- Digitcool, IMV Technology, France) as per Contri et al. [3] and semen straws were plunged into the liquid nitrogen and stored.

Thawing of frozen semen straws was carried out in water using three different methods i.e., $35^{\circ} \mathrm{C}$ for $60 \mathrm{~s}$ (thawing method I), $37^{\circ} \mathrm{C}$ for $30 \mathrm{~s}$ (thawing method II), and $75^{\circ} \mathrm{C}$ for $9 \mathrm{~s}$ (thawing method III). The post-thaw semen quality parameters assessed were sperm motility, percent live sperm, hypo-osmotic swelling test (HOST)-reacted sperm as described by Jeyendran et al. [4], acrosomal changes using Giemsa staining technique of Watson [5], and alanine aminotransferase (ALT) and aspartate aminotransferase (AST) activities in the extracellular media estimated by enzymatic colorimetric method using commercial ENZOKIT (RFCL Limited, Plot No. 37, Pharma City, Selaqui, Dehradun - 248197, Uttarakhand, India) and were expressed in IU/L.

\section{Statistical analysis}

Analyses were performed using the Statistical System software package (SAS, Cary, NC, USA, 2010). Data on different parameters were analyzed using two-factorial analysis of variance (ANOVA) (GLM procedure).

\section{Results}

The mean percentage of motile sperm, live sperm, HOST-reacted sperm, extracellular ALT (IU/L), AST (IU/L), and different acrosomal changes in frozen semen after thawing in water following thawing method I, II, and III are presented in Table-1.
The percent sperm motility $(\mathrm{p}<0.01)$ varied significantly between thawing methods but live sperm and HOST-reacted sperm did not vary significantly between thawing methods. Critical difference test revealed that the percent sperm motility of frozen yak semen for thawing method III was significantly $(p<0.05)$ higher than that for thawing methods I and II, but difference between thawing methods I and II was non-significant. The extracellular release of AST differed significantly $(p<0.01)$ between thawing methods but, ALT did not differ significantly between thawing methods. The extracellular release of AST for thawing methods I and II was significantly $(\mathrm{p}<0.05)$ lower than that for thawing method III.

Analysis of variance revealed that the incidences of the swollen acrosome and total acrosomal changes differed significantly $(p<0.01)$ between thawing methods but the incidence of separating and entirely lost acrosomes did not differ significantly between thawing methods. The critical difference test revealed that the incidence of the swollen acrosome and total incidence of acrosomal changes were significantly $(p<0.05)$ lower when thawing was done using methods I and II than in method III.

\section{Discussion}

In the present study, the percent sperm motility in frozen yak semen was found to be significantly $(p<0.05)$ higher for thawing method III than that for thawing methods I and II. Similar to the present findings, significantly $(\mathrm{p}<0.05)$ higher post-thaw sperm motility in buffalo semen was reported by earlier workers for thawing at $75^{\circ} \mathrm{C}$ for $9 \mathrm{~s}$ than at $37^{\circ} \mathrm{C}$ for $15 \mathrm{~s}[6,7]$ and $37^{\circ} \mathrm{C}$ for $30 \mathrm{~s}$ [8]. The post-thaw motility and kinematic parameters of buffalo spermatozoa were significantly improved immediately after thawing by increasing the thawing rate from $37^{\circ} \mathrm{C}$ in $30 \mathrm{~s}$ to $70^{\circ} \mathrm{C}$ in $6 \mathrm{~s}$ [9]. In bull semen, Lyashenko [10] recorded that progressive motility was significantly increased by thawing at $65-70^{\circ} \mathrm{C}$ for $6-7 \mathrm{~s}$ compared with the thawing rate of $35^{\circ} \mathrm{C}$ for $20 \mathrm{~s}$. Nema et al. [11] also observed significantly higher sperm motility in semen samples thawed at $50^{\circ} \mathrm{C}$ for $8 \mathrm{~s}$ than that thawed at $40^{\circ} \mathrm{C}$ for $8 \mathrm{~s}$ or at $37^{\circ} \mathrm{C}$ for 8 or $15 \mathrm{~s}$. The higher sperm

Table-1: Effect of different thawing methods on various post-thaw sperm parameters.

\begin{tabular}{|c|c|c|c|}
\hline \multirow[t]{2}{*}{ Parameters } & \multicolumn{3}{|c|}{ Thawing methods } \\
\hline & I $\left(35^{\circ} \mathrm{C}\right.$ for $\left.60 \mathrm{~s}\right)$ & II $\left(37^{\circ} \mathrm{C}\right.$ for $\left.30 \mathrm{~s}\right)$ & II $\left(75^{\circ} \mathrm{C}\right.$ for $\left.09 \mathrm{~s}\right)$ \\
\hline Sperm motility (\%) & $64.45^{A} \pm 0.83$ & $64.67^{A} \pm 0.91$ & $66.33^{\mathrm{B}} \pm 1.03$ \\
\hline Live sperm $(\%)$ & $70.05 \pm 0.73$ & $70.40 \pm 0.78$ & $69.87 \pm 0.41$ \\
\hline HOST-reacted sperm (\%) & $57.00 \pm 1.04$ & $59.45 \pm 1.22$ & $58.00 \pm 1.20$ \\
\hline ALT (IU/L) & $11.87 \pm 0.77$ & $11.95 \pm 1.02$ & $12.38 \pm 0.92$ \\
\hline AST (IU/L) & $11.37^{A} \pm 0.65$ & $10.28^{\mathrm{A}} \pm 0.10$ & $14.39^{\mathrm{B}} \pm 0.74$ \\
\hline Swollen acrosome (\%) & $5.50^{A} \pm 0.37$ & $5.10^{\mathrm{A}} \pm 0.19$ & $6.60^{\mathrm{B}} \pm 0.32$ \\
\hline Separating acrosome (\%) & $2.33 \pm 0.23$ & $2.33 \pm 0.19$ & $2.80 \pm 0.20$ \\
\hline Entirely lost acrosome (\%) & $3.47 \pm 0.31$ & $3.87 \pm 0.19$ & $3.73 \pm 0.34$ \\
\hline Total acrosomal changes (\%) & $11.00^{A} \pm 0.62$ & $11.40^{A} \pm 0.27$ & $13.27^{B} \pm 0.53$ \\
\hline
\end{tabular}


motility observed when semen was thawed at higher temperature might be due to that even the weakly motile spermatozoa were moving at a higher velocity. Higher $\left(60^{\circ} \mathrm{C}\right)$ thawing temperatures were also preferred by other workers $[12,13]$. The post-thaw sperm motility did not differ significantly when semen was thawed at $35^{\circ} \mathrm{C}$ for $60 \mathrm{~s}$ or at $37^{\circ} \mathrm{C}$ for $30 \mathrm{~s}$.

In the present study, although not significant, the percentage of live sperm in frozen yak semen was recorded apparently higher for thawing method I and II in comparison to method III. On the contrary, Ahmed [8] obtained a higher percentage of live sperm when frozen buffalo semen was thawed at $75^{\circ} \mathrm{C}$ for $9 \mathrm{~s}$ in comparison with that thawed at $37^{\circ} \mathrm{C}$ for $30 \mathrm{~s}$. The above discrepancies might be due to the differences in processing and freezing protocols used in different studies and the species involved.

The percentage of HOST-reacted sperm was also apparently higher for thawing methods I and II than for thawing method III, but the difference was not significant. Similar observations were also reported by Ahmed [8] in frozen buffalo semen and Sarmah [14] in frozen buck semen. No significant difference in the percentage of HOST-reacted sperm was recorded when thawed at $37^{\circ} \mathrm{C}$ for $30 \mathrm{~s}, 25^{\circ} \mathrm{C}$ for $2 \mathrm{~min}, 50^{\circ} \mathrm{C}$ for $12 \mathrm{~s}$, and $75^{\circ} \mathrm{C}$ for $9 \mathrm{~s}$ was reported by Ahmed [8] and between $37^{\circ} \mathrm{C}$ for $30 \mathrm{~s}, 37^{\circ} \mathrm{C}$ for $2 \mathrm{~min}$, and $40^{\circ} \mathrm{C}$ for $20 \mathrm{~s}$ was by Sarmah [14].

The total incidence of acrosomal changes in yak semen was significantly $(p<0.05)$ lower for thawing methods I and II than that for thawing method III. Although not significant, the extracellular release of ALT was slightly lower when semen was thawed using thawing methods I and II as compared to thawing method III. On the other hand, the extracellular release of AST in frozen semen was found to be significantly $(p<0.05)$ lower when semen was thawed following the method I and II than III. The lower extracellular release of ALT and AST in frozen semen thawed at $35^{\circ} \mathrm{C}$ for $60 \mathrm{~s}$ and at $37^{\circ} \mathrm{C}$ for $30 \mathrm{~s}$ could be due to lower injuries inflicted to cell membrane as evidenced by significantly lower total incidence of acrosomal changes recorded in the study.

The thawing phase of frozen semen is equally important to that of freezing phase as both the stages are to pass through the critical temperature zone i.e., from -5 to $-50^{\circ} \mathrm{C}$ [15] which causes detrimental effect on surviving spermatozoan population. The lipid peroxidation and subsequent membrane damage are at its peak in the frozen-thawed semen [16]. The effect of thawing depends on the rate of freezing, i.e., whether the rate of freezing has been sufficiently high to induce intracellular freezing or slow enough to produce cell dehydration. In the former, fast thawing is required to prevent recrystallization of any intracellular ice present in the spermatozoa. Spermatozoa thawed at a faster rate may be exposed for a shorter time to the concentrated solute and glycerol, and the restoration of the intracellular and extracellular equilibrium is more in rapid thawing than in slow thawing [12,17]. The differences observed in the present study and those indicated by other workers might be explained by the differences in pairing of the freezing rate and thawing method. However, it was recommended that for optimal cell survival, the rate at which the cell is frozen must be matched with a corresponding thaw rate, to reverse the osmotic balance and rehydration of the cell, while preventing intracellular ice formation [18].

\section{Conclusion}

Barring the post-thaw sperm motility, thawing of frozen yak semen in water either at $35^{\circ} \mathrm{C}$ for $60 \mathrm{~s}$ or $37^{\circ} \mathrm{C}$ for $30 \mathrm{~s}$ gives better post-thaw semen quality than at $75^{\circ} \mathrm{C}$ for $9 \mathrm{~s}$ as evident by significantly lesser $(p<0.05)$ incidence of swollen acrosome, total acrosomal changes, and extracellular AST release. The percentage of live sperm, HOST-reacted sperm, extracellular ALT release, and incidence of separating acrosome was also recorded better; however, the differences were non-significant.

\section{Authors' Contributions}

BKDB carried out the research work as a part of his Ph. D thesis. BCD and PC conceptualized and formulated the experimental design. SD supervised the experiment and drafted the manuscript. RKB, SS, and KA analyzed the data and revised the manuscript. All authors read and approved the manuscript.

\section{Acknowledgments}

The authors are grateful to the Director, ICAR- National Research Centre on Yak, Dirang, Arunachal Pradesh for providing research facilities in the form of infrastructures and consumables.

\section{Competing Interests}

The authors declare that they have no competing interests.

\section{References}

1. Dobrin, N., Zamfirescu, S., Coprean, D. and Anghel, A.H. (2014) Effect of thawing time and temperature variation on the quality of frozen-thawed ram semen. Rom. Biotechnol. Lett., 19(1): 8935-8940.

2. Al-Badry, I.K. (2012) Effect of various thawing times and temperatures on frozen semen quality of Friesian bulls in Iraq. Inter. J. Anim. Vet. Adv., 4(6): 384-388.

3. Contri, A., Valorz, C., Faustini, M., Wegher, L. and Carluccio, A. (2010) Effect of semen preparation on CASA motility results in cryopreserved bull spermatozoa. Theriogenology, 74: 424-453.

4. Jeyendran, R.S., Vander-Ven, H.H., Perez-Pelaez,M., Crabo, B.G. and Zanevld, L.J. (1984) Development of an assay to assess the functional integrity of the human sperm membrane and its relationship to other semen characters. J. Reprod.Fert., 70(1): 219-228.

5. Watson, P.F. (1975) Use of Giemsa stain to detect changes in the acrosome of frozen ram spermatozoa. Vet. Rec.,97(1): 12-15.

6. Ahmad, K. (1984) Effect of thaw rates on survival of buffalo spermatozoa frozen in straws. J. Dairy Sci., 67(7): $1535-1538$

7. Rao, A.V., Haranath, G.B., Sekharam, G.S. and 
Ramamohana, J. (1990) Effect of thaw rates on motility, survival and acrosomal integrity of buffalo spermatozoa frozen in medium French straws. Indian Vet. J., 12: 123-129.

8. Ahmed, M.U. (2011) Effect of freezing rate and thawing method on quality of frozen Swamp buffalo semen. M.V.Sc., Thesis Submitted to Assam Agricultural University, Khanapara, Guwahati, India.

9. Rastegarnia, A.R., Shahverdi, A.H., RezaeiTopraggaleh, T., Ebrahimi, B. and Shafipour, V. (2013) Effect of different thawing rates on post-thaw viability, kinematic parameters and chromatin structure of buffalo (Bubalus bubalis) spermatozoa.Cell J., 14(4): 306-313.

10. Lyashenko, A. (2015) Effect of different thawing procedures on the quality and fertility of the bull spermatozoa. Asian Pac. J. Reprod., 4(1): 17-21.

11. Nema, S.P., Dhami, A.J. and Kavani, F.S. (2009) Effect of thawing regime on post-thaw quality of ram semen frozen in tris, citrate and phosphate based diluents. Indian Vet. $J ., 86(5):$ 478-480.

12. Fiser, P.S., Ainsworth, L. and Faithfull, R.W. (1987) Evaluation of new diluent and different processing procedures for cryopreservation of ram semen. Theriogenology, 28(5): 599-607.
13. Kumar, D. and Naqvi, S.M. (2014) Effect of time and depth of insemination on fertility of Bharat Merino sheep inseminated trans-cervical with frozen-thawed semen. J. Anim. Sci. Tech., 56:8. Available from:http://www.janimscitechnol.com. Retrieved on 28-2-2015.

14. Sarmah, J.P. (2011) Effect of freezing rate and thawing method on quality of frozen Goat semen. M.V.Sc., Thesis Submitted to Assam Agricultural University, Khanapara, Guwahati, India.

15. Marshall, C.E. (1984) Considerations of cryopreservation of semen. Zoo Biol.,3(4): 343-356.

16. Kadirvel, G., Kumar, S., Ghosh, S.K. and Perumal, P. (2014) Activity of antioxidative enzymes in fresh and frozen thawed buffalo (Bubalus bubalis) spermatozoa in relation to lipid peroxidation and semen quality.Asian Pac. J. Reprod., 3(3): 210-217.

17. Salamon, S. and Maxwell, W.M. (2000) Storage of ram semen. Anim. Reprod. Sci., 62(1-3): 77-111.

18. Mazur, P. (1985) Basic concepts in freezing cells. In: Johnson, L.A. and Larsson, K., editors. Deep Freezing of Boar Semen. Swedish University of Agricultural Sciences, Uppsala. p91-111. 